Original Research Article

\title{
Prevalence of obesity, hypertension and metabolic abnormalities in patients receiving long term cART: a case control study from South India
}

\author{
Vasudeva Acharya*, Govind Gangadharan
}

\begin{abstract}
Department of Medicine, Kasturba Medical College, Manipal University, Manipal, Karnataka, India
\end{abstract}

Received: 12 June 2017 Accepted: 19 June 2017

\section{*Correspondence to: Dr. Vasudeva Acharya, Email: acharyavasudev@ yahoo.com}

Copyright: (C) the author(s), publisher and licensee Medip Academy. This is an openaccess article distributed under the terms of the Creative Commons Attribution NonCommercial License, which permits unrestricted noncommercial use, distribution, and reproduction in any medium, provided the original work is properly cited.

\begin{abstract}
Background: Combination antiretroviral therapy (cART) has improved the quality of life and survival of HIV-infected individuals. However, the long term intake of these drugs is associated with multiple metabolic abnormalities eventually leading to increased risk for cardiovascular morbidity and mortality. Methods: Forty five HIV-infected individuals who are on cART having CD4+ cell count of $>200$ cells $/ \mathrm{mm}^{3}$ for at least 2 years were recruited as cases. Age and gender matched, otherwise healthy individuals were taken as controls. Both cases and controls were compared for the prevalence of obesity, abdominal obesity, hypertension, diabetes mellitus and lipid abnormalities.

Results: We found higher prevalence of obesity (33.3\% vs $26.7 \%$ ), abdominal obesity $(33.3 \%$ vs $17.8 \%)$, hypertension $(33.3 \%$ vs $20 \%)$, impaired fasting glucose (IFG) (37.7\% vs $8.9 \%$ ), diabetes mellitus ( $26.7 \%$ vs $24.4 \%$ ), high total cholesterol (33.3\% vs 22.2\%) and low HDL cholesterol (60\% vs $46.7 \%$ ) among cases compared to controls. The statistically significant difference was noted only for IFG (cases $=17,37.7 \%$, controls $=4,8.9 \%$, p value $=0.002$ ). Low HDL cholesterol was the most common metabolic abnormality found in 27 $(60 \%)$ cases and $21(46.7 \%)$ controls.

Conclusions: HIV-infected individuals receiving long term cART have higher prevalence of obesity, hypertension and dysregulations in glucose and lipid metabolism compared to general population and hence, the diagnosis and management of these abnormalities is very important to prevent cardiovascular morbidity and mortality.
\end{abstract}

Keywords: Combination antiretroviral therapy, Diabetes mellitus, HIV infection, Hypertension, Metabolic disorders

\section{INTRODUCTION}

Combination antiretroviral therapy (cART) is the mainstay of treatment for patients living with HIV/AIDS. The aim of cART is to suppress the viral replication and thereby improving the function of immune system which has been proved by reduction in circulating viral load and improvements in CD4+ cell count. Survival benefits from cART have been unequivocally proven but questions have been raised about safety of using these medications for unlimited period of time. Long term use of cART has resulted in multiple metabolic abnormalities including dyslipidemia, lipodystrophy, dysregulations in glucose metabolism and increased risk of coronary artery disease. ${ }^{1-4}$ This has been proven by different studies done in developed countries. However, there is a lack of literature on this issue from developing countries. There are reports from African countries about increased prevalence of metabolic syndrome in patients receiving cART. $^{5,6}$ A recent study from Uganda (CoLTART) involving HIV-infected individuals on cART, did not find increased occurrence of renal dysfunction in patients receiving tenofovir containing regimen but recommended regular cardiovascular risk assessment along with 
preventive and therapeutic measures against metabolic diseases. $^{7}$ Meanwhile a meta-analysis revealed no significant association between HIV infection or treatment and type 2 diabetes mellitus prevalence in African population studies. ${ }^{8}$

This study was aimed to assess the prevalence of hypertension, obesity and metabolic abnormalities including blood sugar and lipid profile in patients receiving cART.

\section{METHODS}

A cross sectional case control study was conducted over a period of two years in a tertiary referral hospital situated in West coast of South India.

Patients aged more than 18 years living with AIDS receiving cART, having a minimum of 4 values of CD4+ count of above 200 cells/ $\mathrm{mm}^{3}$ in the past 2 years were included in the study. The patients with history of overweight, hypertension, dyslipidemia, impaired fasting glucose or diabetes mellitus prior to initiation on cART were excluded. A total of 45 patients were included in the study. An equal number of age and gender matched asymptomatic subjects attending outpatient clinic or health check clinic were recruited as controls. The controls did not have documented high blood pressure or abnormalities in metabolic parameters in the past.

American Diabetic Association criteria was used for diagnosis of impaired fasting glucose (IFG) and diabetes mellitus. IFG = fasting plasma glucose of 100 to $125 \mathrm{mg} / \mathrm{dL}$. Diabetes mellitus is diagnosed if fasting plasma glucose is $\geq 126 \mathrm{mg} / \mathrm{dL}$ or/and $\mathrm{HbA} 1 \mathrm{C} \geq 6.5 \mathrm{gm} \%$. Patients are also considered to be diabetic if they are on glucose lowering therapy.

Total cholesterol (TC) $>200 \mathrm{mg} / \mathrm{dL}$ and LDL cholesterol $>130 \mathrm{mg} / \mathrm{dL}$ were considered high. Serum triglycerides $>150 \mathrm{mg} / \mathrm{Dl}$ was considered as abnormal. Blood pressure above 140/90 mm of $\mathrm{Hg}$ (2 recordings) was considered as hypertension. Patients receiving antihypertensive therapy were also considered to have hypertension. Body mass index (BMI) of $23-24.9 \mathrm{~kg} / \mathrm{m}^{2}$ was considered overweight and $\geq 25 \mathrm{~kg} / \mathrm{m}^{2}$ was considered as obesity. Abdominal obesity was considered to be present if the waist circumference was $\geq 90 \mathrm{~cm}$ in men and $\geq 80 \mathrm{~cm}$ in women. ${ }^{9}$

\section{Data analysis}

The results were analyzed using SPSS version 22. The statistical analysis was carried out using Fischer's exact probability test; two tailed $\mathrm{p}$ value $<0.05$ taken as significant. In order to study the prevalence of metabolic abnormalities in patients treated with cART, a null hypothesis was formulated as "there is no significant difference in metabolic profile between patients on cART and age matched controls".

\section{RESULTS}

Forty five cases and forty five age and gender matched controls were included in this study. The mean age of cases was $49 \pm 11$ years and of controls was 50.5 \pm 14.3 years. There were 34 males and 11 females in each group. Twenty eight $(62.2 \%)$ individuals in each group belonged to the age group 40-59 years (Table 1).

Table 1: Base line characteristics of cases and controls.

\begin{tabular}{|llll|}
\hline Age (years) & Mean & $\begin{array}{l}\text { Cases } \\
(\mathbf{n = 4 5})\end{array}$ & $\begin{array}{l}\text { Controls } \\
(\mathbf{n}=\mathbf{4 5})\end{array}$ \\
\hline & $20-29$ & 2 & $50.5 \pm 14.3$ \\
\hline & $30-39$ & 9 & 2 \\
\hline & $40-49$ & 17 & 9 \\
\hline & $50-59$ & 11 & 11 \\
\hline & $60-69$ & 4 & 4 \\
\hline Gender & $70-79$ & 2 & 2 \\
\hline & Male & 34 & 34 \\
\hline & Female & 11 & 11 \\
\hline
\end{tabular}

Thirty five cases were on first line cART comprising zidovudine/tenofovir, lamivudine/emtricitabine and nevirapine/efavirenz. Ten cases were on boosted protease inhibitor based second line cART. All patients were on regular follow up and were adherent to therapy. The total duration of therapy ranged from 4 years to 13 years. All cases had CD4+ cell count above 200 cells $/ \mathrm{mm}^{3}$ at least on 4 occasions during the past 2 years. The mean CD4+ cell count of cases done during the study period was $454 \pm 258$, the highest and the lowest being 1774 cells $/ \mathrm{mm}^{3}$ and 210 cells $/ \mathrm{mm}^{3}$ respectively.

The overweight/obesity was noted in 15 (33.3\%) cases and $12(26.7 \%)$ controls. The mean BMI of cases and controls was $23.4 \pm 2.9 \mathrm{~kg} / \mathrm{m}^{2}$ and $23.8 \pm 2.3 \mathrm{~kg} / \mathrm{m}^{2}$ respectively.

Hypertension was observed in $15(33.3 \%)$ cases and 9 (20\%) controls. Among the cases with hypertension, 7 were receiving antihypertensive therapy at the time of study and the remaining 8 cases were detected to have hypertension during study. All the 9 subjects with hypertension among controls were diagnosed for the first time during study.

Diabetes mellitus and impaired fasting glucose (IFG): (Table 2). Normal fasting glucose was noted in 16 $(35.5 \%)$ cases and $30(67.7 \%)$ controls. The number of cases having diabetes mellitus was almost same in both groups, however the prevalence of IFG was $17(37.7 \%)$ among cases while it was $4(8.9 \%)$ among controls.

We analysed the prevalence of IFG and diabetes mellitus in cases according to age. Cases were divided into two groups, age less than 50 years and age $\geq 50$ years (Table 
$3)$. The normal fasting glucose was observed in 7 (41.2\%) cases with age $\geq 50$ years when compared to 9 cases $(32.1 \%)$ with age less than 50 years.

The prevalence of diabetes mellitus was more (32.1\%) among cases aged less than 50 years compared to cases aged 50 years or above $(17.6 \%)$.

Table 2: Fasting blood sugar among cases and controls.

\begin{tabular}{|lll|}
\hline $\begin{array}{l}\text { Fasting blood } \\
\text { sugar }\end{array}$ & $\begin{array}{l}\text { Number of } \\
\text { cases }(\mathbf{n = 4 5})\end{array}$ & $\begin{array}{l}\text { Controls } \\
(\mathbf{n}=\mathbf{4 5})\end{array}$ \\
\hline$<100 \mathrm{mg} / \mathrm{dL}$ & $16(35.5 \%)$ & $30(67.7 \%)$ \\
\hline $100-125 \mathrm{mg} / \mathrm{dL}$ & $17(37.7 \%)$ & $4(8.9 \%)$ \\
\hline$\geq 126 \mathrm{mg} / \mathrm{dL}$ & $12(26.7 \%)$ & $11(24.4 \%)$ \\
\hline
\end{tabular}

Table 3: Prevalence of high blood sugar among cases according to age.

\begin{tabular}{|llll|}
\hline & $\begin{array}{l}\text { Age }<\mathbf{5 0} \\
\text { years } \\
(\mathbf{n = 2 8})\end{array}$ & $\begin{array}{l}\text { Age } \geq \mathbf{5 0} \\
\text { years } \\
(\mathbf{n}=\mathbf{1 7})\end{array}$ & $\begin{array}{l}\text { Total } \\
(\mathbf{n = 4 5})\end{array}$ \\
\hline $\begin{array}{l}\text { Fasting } \\
\text { blood sugar } \\
<100 \mathrm{mg} / \mathrm{dL}\end{array}$ & $9(32.1 \%)$ & $7(41.2 \%)$ & $16(35.5 \%)$ \\
\hline IFG & $10(35.7 \%)$ & $7(41.2 \%)$ & $17(37.7 \%)$ \\
\hline $\begin{array}{l}\text { Diabetes } \\
\text { mellitus }\end{array}$ & $9(32.1 \%)$ & $3(17.6 \%)$ & $12(26.7 \%)$ \\
\hline
\end{tabular}

The mean values of fasting blood sugar, total cholesterol, LDL cholesterol and triglycerides were higher in cases compared to controls. The mean of HDL cholesterol was lower in cases than controls (Table 4).

Table 4: Fasting blood sugar and lipid profile among cases and controls.

\begin{tabular}{|lll|}
\hline Parameter & $\begin{array}{l}\text { Mean among } \\
\text { cases }(\mathrm{mg} / \mathrm{dL})\end{array}$ & $\begin{array}{l}\text { Mean among } \\
\text { controls } \\
\text { (mg/dL) }\end{array}$ \\
\hline $\begin{array}{l}\text { Fasting blood } \\
\text { sugar }\end{array}$ & $107.4 \pm 24.7$ & $107.3 \pm 36.8$ \\
\hline Total cholesterol & $172 \pm 35.1$ & $156.5 \pm 33.3$ \\
\hline LDL cholesterol & $107.8 \pm 28.2$ & $102.6 \pm 29.7$ \\
\hline HDL cholesterol & $39.9 \pm 12$ & $40.9 \pm 13.8$ \\
\hline Triglycerides & $140.9 \pm 27.4$ & $139.9 \pm 25.9$ \\
\hline
\end{tabular}

Comparison of variables between cases and controls: Almost all the parameters studied were observed in more number of cases compared to controls.

The most common abnormality was low HDL cholesterol which was noted in $27(60 \%)$ cases and $21(46.7 \%)$ controls.

However, the statistically significant difference was noted only for impaired fasting glucose with $\mathrm{p}$ value of 0.002 (Table 5).
Table 5: Prevalence of each variable among cases and controls.

\begin{tabular}{|lllll|}
\hline Parameters & $\begin{array}{l}\text { Cases } \\
\mathbf{n = 4 5} \\
(\%)\end{array}$ & $\begin{array}{l}\text { Controls } \\
\mathbf{n}=\mathbf{4 5} \\
(\%)\end{array}$ & $\begin{array}{l}\mathbf{p} \\
\text { value }\end{array}$ & $\begin{array}{l}\text { OR } \\
(\mathbf{9 5} \% \mathbf{C I})\end{array}$ \\
\hline $\begin{array}{l}\text { Overweight/o } \\
\text { besity }\end{array}$ & $\begin{array}{l}15 \\
(33.3)\end{array}$ & $12(26.7)$ & 0.64 & $\begin{array}{l}1.37 \\
(0.55,3.4)\end{array}$ \\
\hline $\begin{array}{l}\text { Abdominal } \\
\text { obesity }\end{array}$ & $\begin{array}{l}15 \\
(33.3)\end{array}$ & $8(17.8)$ & 0.14 & $\begin{array}{l}2.3 \\
(0.86,6.18)\end{array}$ \\
\hline Hypertension & $\begin{array}{l}15 \\
(33.3)\end{array}$ & $9(20)$ & 0.23 & $2(0.76,5.2)$ \\
\hline $\begin{array}{l}\text { Diabetes } \\
\text { mellitus }\end{array}$ & $\begin{array}{l}12 \\
(26.7)\end{array}$ & $\begin{array}{l}11 \\
(24.4)\end{array}$ & 0.99 & $\begin{array}{l}1.1 \\
(0.43,2.9)\end{array}$ \\
\hline IFG & $\begin{array}{l}17 \\
(37.7)\end{array}$ & $4(8.9)$ & 0.002 & $\begin{array}{l}6.2 \\
(1.89,20.4)\end{array}$ \\
\hline High TC/LDL & $\begin{array}{l}15 \\
(33.3)\end{array}$ & $10(22.2)$ & 0.34 & $\begin{array}{l}1.75 \\
(0.68,4.4)\end{array}$ \\
\hline $\begin{array}{l}\text { High } \\
\text { triglycerides }\end{array}$ & $\begin{array}{l}16 \\
(35.6)\end{array}$ & $13(28.9)$ & 0.65 & $\begin{array}{l}1.35 \\
(0.55,3.2)\end{array}$ \\
\hline Low HDL & $\begin{array}{l}27 \\
(60.0)\end{array}$ & $21(46.7)$ & 0.29 & $\begin{array}{l}1.7 \\
(0.74,3.9)\end{array}$ \\
\hline
\end{tabular}

\section{DISCUSSION}

This case control study was conducted to assess the prevalence of obesity, hypertension and metabolic derangements occurring in patients receiving antiretroviral medications. Advanced HIV disease itself is associated with increased cardiovascular risk. ${ }^{10,11}$ However we recruited the cases receiving cART who are doing well, evidenced by CD4+ cell count of above 200 cells $/ \mathrm{mm}^{3}$ for at least past 2 years. Hence, the metabolic abnormalities observed are most likely due to the result of long term use of antiretroviral medications or reconstituted immunity and unlikely to be due to the advanced HIV disease. These cases are likely to be having well suppressed HIV viral load even though we have not checked it in most of the subjects due to financial constraints. In the literature, there are evidences to suggest the increasing incidence of non-AIDS related complications, particularly metabolic disorders in patients receiving cART. ${ }^{12}$

In our study, the prevalence of hypertension, overweight/obesity and abdominal obesity was found to be more in cases than controls, however the difference was not statistically significant. The prevalence of hypertension was $33.3 \%$ among cases, while it was $20 \%$ among controls. In a study conducted by Gazzaruso $\mathrm{C}$ in Italy, the prevalence of hypertension in patients receiving cART was very high (42.3\%) compared to age and gender matched HIV negative controls. ${ }^{4}$ Begersen and colleagues from Norway, reported the prevalence of hypertension as $21 \%$ in patients receiving cART, $13 \%$ in HIV positive but cART naïve individuals and $24 \%$ in HIV negative controls. ${ }^{13}$ The cART naïve, HIV-infected patients are generally malnourished and emaciated and hence the low prevalence of hypertension was noted in 
this group in the above study. However, we did not include patients from this category.

The difference in the prevalence of abdominal obesity among cases and controls $(15$ and $8, p$ value $=0.14)$ was more when compared to the difference in BMI (15 and $12, \mathrm{p}$ value $=0.64)$. Lipodystrophy observed while on cART is the likely reason for fat redistribution contributing for increased abdominal fat deposition.

We noticed a higher prevalence of IFG, diabetes mellitus, elevated total and LDL cholesterol, elevated triglycerides and low HDL cholesterol among the cases compared to the controls. The difference was statistically significant only for IFG ( $p$ value 0.002). Among cases, low HDL cholesterol was the most common abnormality $(27,60 \%)$ followed by IFG $(17,37.7 \%)$. Incidentally the most common metabolic abnormality among controls was also low HDL cholesterol $(21,46.7 \%)$. Calza and colleagues reported higher prevalence of metabolic syndrome with patients on first line antiretroviral therapy $(20.9 \%)$ when compared to treatment naïve patients $(7.1 \%) .{ }^{14}$ They also reported high triglycerides as the most common abnormality (44.3\%) followed by low HDL cholesterol (41.1\%) among components of metabolic syndrome. A study from South West region of Cameroon compared the prevalence of metabolic abnormalities in patients receiving cART $(n=157)$ and cART naïve $(n=57)$ patients. The prevalence of high total cholesterol was $51 \%$ in patients on cART while it was $9.6 \%$ in patients not been started on cART ( $\mathrm{p}$ value $=<0.0001) .{ }^{5}$

Evidence from Medical Monitoring Project $(n=8610$ HIV - infected adults) and National Health and Nutrition Examination Survey $(n=5604$ general population) from United States suggested the prevalence of diabetes mellitus among HIV-infected adults as $10.3 \%$ (95\% CI $9.2 \%$ to $11.5 \%$ ) and it was $3.8 \%$ higher compared to general population adults. ${ }^{15} \mathrm{We}$ did not observe significant difference in the prevalence of diabetes mellitus among cases and controls $(26.7 \%$ and $24.4 \%$ respectively). However, the prevalence of IFG was very high in cases compared to controls $(37.7 \%$ and $8.9 \%$ respectively). Incidentally we observed relatively high occurrence of diabetes mellitus $(24.4 \%)$, elevated triglycerides $(28.9 \%)$ and low HDL cholesterol (46.7\%) in control population also in our study compared to Western countries which is an established fact and has been quoted in literature. Hence it is difficult to prove the significant association between consumption cART and prevalence of metabolic parameters in India. The high prevalence of diabetes mellitus in control group when compared to national prevalence could not be explained and may be attributed to bias in selection of controls as many of them were recruited from health check.

It is well known that the prevalence of IFG or diabetes mellitus increases with increasing age. When we analyzed the cases with abnormal glucose tolerance according to age (age $<50$ years or age $\geq 50$ years), no significant difference was noted in the prevalence in two groups.

The contribution from individual antiretroviral drug to the abnormalities in metabolic profile could not be analyzed because multiple antiretroviral regimens were used in the cases studied. However, among the 10 cases on second line therapy consisting of boosted protease inhibitor, majority had significant metabolic abnormalities. Obesity was seen in $9(90 \%)$ cases and hypertension in 8 cases $(80 \%)$. The most common metabolic abnormality was IFG which was observed in 7 cases $(70 \%)$. It is well established that protease inhibitor based therapy is associated with increased incidence of dyslipidemia. The other reason for higher prevalence of metabolic abnormalities in patients on $2^{\text {nd }}$ line cART could be the longer duration of therapy they are on, as all of them were on $1^{\text {st }}$ line cART for many years before being changed to $2^{\text {nd }}$ line medications because of failure.

\section{CONCLUSION}

The results of this study indicate that people living with HIV/AIDS receiving cART, having good immune function have a high prevalence of overweight/obesity, hypertension, IFG, diabetes mellitus and dyslipidemia when compared to age and gender matched controls. However, the difference in prevalence was statistically significant only for IFG. While caring for patients on long term optimal cART, it would be a prudent practice to regularly screen them for metabolic abnormalities, as these factors contribute to the cardiovascular morbidity and mortality.

\section{Funding: No funding sources Conflict of interest: None declared \\ Ethical approval: The study was approved by the Institutional Ethics Committee of Kasturba Medical College and Kasturba Hospital, Manipal}

\section{REFERENCES}

1. Wand H, Calmy A, Carey DL, Samaras K, Carr A, Law MG, et al. Metabolic syndrome, cardiovascular disease and type 2 diabetes mellitus after initiation of antiretroviral therapy in HIV infection. AIDS. 2007;21(18):2445-53.

2. Jacobson DL, Tang AM, Spiegelman D, Thomas AM, Skinner S, Gorbach SL, et al. Incidence of metabolic syndrome in a cohort of HIV-infected adults and prevalence relative to the US population (National Health and Nutrition Examination Survey). J Acquir Immnune Defic Syndr. 2006;43(4):458-66.

3. Jerico C, Knobel H, Montero M, Ordonez-Llanos J, Guelar A, Gimeno JL, et al. Metabolic syndrome among HIV-infected patients: prevalence, characteristics and related factors. Diabetes Care. 2005;28(1):132-7.

4. Gazzaruso C, Sacchi P, Garzaniti A, Fratino P, Bruno R, Filice G. Prevalence of metabolic syndrome 
among HIV patients. Diabetes Care. 2002;25(7):1253-4

5. Nsagha DS, Weledji EP, Assob NJ, Njunda LA, Tanue EA, Kibu OD, et al. Highly active antiretroviral therapy and dyslipidemia in people living with HIV/AIDS in Fako division, South West region of Cameroon. BMC Cardiovasc Disord. 2015;15:95.

6. Abede M, Kinde S, Belay G, Gebreegziabxier A, Challa F, Gebeyehu T, et al. Antiretroviral treatment associated hyperglycemia and dyslipidemia among HIV infected patients at Burayu Health Center, Addis Ababa, Ethiopia: a cross sectional comparative study. BMC Res Notes. 2014;7:380.

7. Mayanja BN, Kasamba I, Levin J, Namakoola I, Kazooba P, Were J, et al. COHORT Profile: The complications of Long-Term Antiretroviral Therapy study in Uganda (CoLTART). A prospective clinical cohort. AIDS Res Ther. 2017;14:26

8. Prioreschi A, Munthali RJ, Soepnel L, Goldstein JA, Micklesfield LK, Aronoff DM, et al. Incidence and prevalence of type 2 diabetes mellitus with HIV infection in Africa: A systematic review and metaanalysis. BMJ Open. 2017;7(3):e013953.

9. Enas EA, Singh V, Munjal YP, Gupta R, Patel KC, Bhandari S, et al. Recommendations of the second Indo-US health summit on prevention and control of cardiovascular disease among Asian Indians. Indian Heart Journal. 2008 Dec;61(3):265-74.

10. Pallela FJ, Phair JP. Cardiovascular disease in HIV infection. Curr Opin HIV AIDS. 2011;6(4):266-71.

11. Kaplan RC, Kingsley LA, Gange SJ, Benning L, Jacobson LP, Lazar J, et al. Low CD+ T cell count as a major atherosclerosis risk factor in HIV-infected women and men. AIDS. 2008;22(13):1615-24.

12. Bradbury RA, Samaras K. Antiretroviral therapy and the human immunodeficiency virus-improved survival but at what cost? Diabetes Obes Metab. 2008;10:442-50.

13. Bergersen BM, Sandvik L, Dunlop O, Birkeland K, Bruun JN. Prevalence of hypertension in HIVpositive patients on highly active retroviral therapy (HAART) compared with HAART-naive and HIVnegative controls: results from a Norwegian study of 721 patients. Eur J Clin Microbiol Infect Dis. 2003;22(12):731-6.

14. Calza L, Colangeli V, Maqistrelli E, Rossi N, Roselli Del Turco E, et al. Prevalence of metabolic syndrome in HIV infected patients naïve to antiretroviral therapy or receiving a first line treatment. HIV Clin Trials. 2017;19:1-8.

15. Hernandez-Romieu AC, Garg S, Rosenberg ES, Thompson-Paul AM, Skarbinski J. Is diabetes prevalence higher among HIV-infected individuals compared with the general population? Evidence from MMP and NHANES 2009-2010. BMJ Open Diabetes Res Care. 2017;5(1):e 000304.

Cite this article as: Acharya V, Gangadharan G. Prevalence of obesity, hypertension and metabolic abnormalities in patients receiving long term cART: a case control study from South India. Int J Basic Clin Pharmacol 2017;6:1620-4. 